\title{
Method to assess the atmospheric pollutant emissions generated by railway track maintenance
}

\author{
Jéssica Ferrari Araujo ${ }^{\mathrm{a}}$ (D), Thainá Fardin Damascena ${ }^{\mathrm{a}}$ (D), Rodrigo de Alvarenga Rosa ${ }^{\mathrm{a} *}$ (D), \\ Patrício José Moreira Pires ${ }^{\mathrm{a}}$ (D), Bernardo Bicalho Carvalhaes ${ }^{\mathrm{a}}$ (D), Rafaella Ribeiro Caliman ${ }^{\mathrm{a}}$ (i) \\ aniversidade Federal do Espírito Santo, Vitória, ES, Brasil \\ *rodrigo.a.rosa@ufes.br
}

\begin{abstract}
Paper aims: Propose a method to calculate and evaluate the pollutants emissions generated by the track maintenance process considering the life cycle of the three components: ballast, sleepers and rail.

Originality: After the literature review, we did not find any published research that quantifies, in an integrated way, the atmospheric pollutants emissions generated by the track maintenance process considering each component life cycle.

Research method: The proposed method was based on the life Cycle Assessment (LCA) methodology. The method was applied to Vitória-Minas Railway (EFVM) using its own data and data from its suppliers.

Main findings: Results show that production and delivery is the phase that emits more because of the distance from the supplier to EFVM. Two maintenance locations were tested to evaluate the impact of maintenance distance in the emissions. Several analyses were done for each pollutant emission in each phase.

Implications for theory and practice: The method can be used by any railway, helping managers to adopt more sustainable strategies.

Keywords

Ballast. Sleeper. Rail. Life cycle assessment. Atmospheric pollutants emissions.

How to cite this article: Araujo, J. F., Damascena, T. F., Rosa, R. A., Pires, P. J. M., Carvalhaes, B. B., Caliman, R. B. (2020). Method to assess the atmospheric pollutant emissions generated by railway track maintenance. Production, 30, e20190037. https://doi.org/10.1590/0103-6513.20190037
\end{abstract}

Received: May 02, 2019; Accepted: Nov. 18, 2019.

\section{Introduction}

The Brazilian railway network represents 25\% of Brazil’s cargo transportation (Associação Nacional dos Transportadores Ferroviários, 2018), which demonstrates the economic relevancy of railways. However they cause several environmental impacts due to the emission of atmospheric pollutant generated in the maintenance process and cargo transport.

This paper deals with the maintenance of the track, which is a part of the railway that receives the direct impacts of the train. Its main components are: the ballast, the sleepers and the rails.

This paper proposes a method, based on Life Cycle Assessment (LCA), ruled by the NBR ISO 14,040 (Associação Brasileira de Normas Técnicas, 2014), to calculate and evaluate the pollutants emissions generated by the track maintenance process. To do so, it is analyzed the life cycles of its main components: ballast, sleeper and rail. To validate it, the method was applied to the maintenance process of the track of Vitória-Minas Railway (EFVM). After the literature review, as far as we know, we did not find any published research that quantifies the atmospheric pollutant emissions generated by the track maintenance process. This paper differentiates itself from the others by proposing a method based in the LCA to evaluate in an integrated way the pollutant emission from the ballast, the sleeper and the rail, in the track maintenance process. 
LCA is a method that establishes that the environmental evaluation of any process, product or activity must include the analysis of the complete life cycle, and therefore the approach used by the LCA is known as cradle to grave. We present next a literature review about the application of the LCA methodology to the environmental impact of the track maintenance proccess. Kiani et al. (2008) did a study using LCA of three constructive forms in high speed railway lines for passengers: one with ballast, one without ballast using concrete and another specific technique, called Rheda. They didn't consider rail analysis. The comparison showed that the concrete slab railbed have better environmental performance than the ballast trackbed.

Werner \& Shragle (2008) compared concrete, steel and wooden sleeper impact categories. The steel sleeper presented the biggest contributions of all the impact categories. When the steel sleeper recovery was considered due to its recycling, the concrete sleepers caused the biggest environmental impacts. Stripple \& Uppenberg (2010) developed models for the creation of the Environmental Product Declaration (EPD) of railway components. The authors concluded that the biggest contribution in all categories of impact comes from the acquisition of raw materials used, like cement and concrete.

This paper has five sections, the first is the introduction. Section 2 presents the proposed method for environmental impact evaluation of the track of a railway. Section 3 touches the case study and the data collection of the EFVM, to validate the method proposed in section 3. Section 4 presents the results and data obtained. Section 5 is focused on the conclusions and future works.

\section{Method}

The proposed method is based upon the Brazilian norm NBR ISO 14,040 (Associação Brasileira de Normas Técnicas, 2014). The method is divided in 5 steps (Figure 1): 1) the definition of the railway; 2) the supplier's identification; 3) data obtaining; 4) The emission calculations and 5) the analysis of the results. In Step 1, the railway to be analyzed is chosen. In Step 2, the ballast, sleeper and rail suppliers are chosen. In Step 3, the data collection about the ballast, sleeper and rail is done. In Step 4, the calculations of the emissions of $\mathrm{CO}_{2}, \mathrm{CO}, \mathrm{NO}_{x}$ and MP are done (considering the data obtained in Step 3).

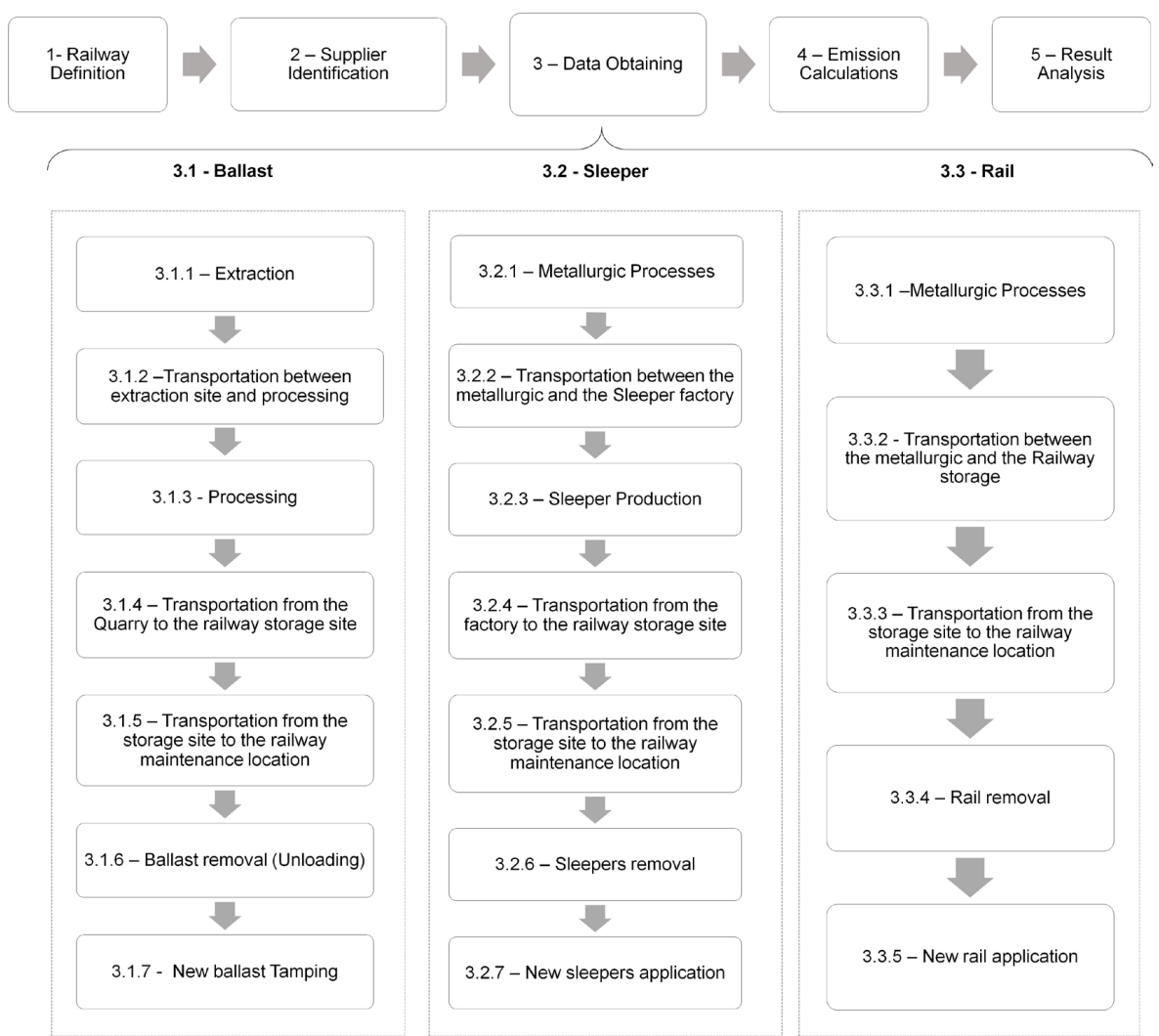

Figure 1. Steps, stages and sub-stages of the proposed method. 
It can be adapted to reach other objectives desired, and the user can alter the frontiers, the functional unity or choose other pollutants. To develop it, there was a necessity to define the essential elements: functional unity, the atmospheric pollutants to be analyzed and the system frontiers.

The selected functional unity, that represents the unity in which the emissions will be quantified, was the kilometer $(\mathrm{km})$. The pollutants analyzed were: Carbon Dioxide $\left(\mathrm{CO}_{2}\right)$, Carbon Monoxide (CO), Nitrogen Oxides $\left(\mathrm{NO}_{\mathrm{x}}\right)$ and Particulate Matter (MP).

The system frontiers define the processes that will be a part of the life cycle analysis of each product. Step 3, Figure 1, is divided in three stages, each is divided, in several sub-stages, described next. Stages For 3.1, 3.2 and 3.3 deals, respectively with the ballast, the sleeper and the rail. They represent the system frontiers.

We propose four phases to analyze the results: 1) Production and material delivery (goes through the extraction of the raw materials to the delivery at the railway storage site); 2) Transportation from the railway storage site to the track maintenance location; 3) Removal of the ballast, sleepers and rails and 4) Installing new ballast, sleepers and rails. Phases 3 and 4 happen at the track maintenance location.

Following, we present the parameters, the variables and the proposed Equations 1-13 to calculate the emissions for the Step 4 based on the four phases mentioned before. We defined set $E$ as the set of pollutants which will be evaluated by the method. It has four pollutants: $1-\mathrm{CO}_{2} ; 2-\mathrm{CO} ; 3-\mathrm{NOx}$ and $4-\mathrm{MP}$.

${ }_{E}$ Set of evaluated pollutants, $E=\{1, \ldots, 4\}$

Emissions are calculated separately for the ballast, sleeper and the rail, and after that, the total emission is calculated. Equations 1-4 are used to calculate the emissions of ballast for one kilometer of track.

$$
\begin{gathered}
t e l L K_{i}=m 3 k l\left(\text { elEx }_{i}+e l T p_{i}+e l B e_{i}+\text { dpalelTf }_{i}\right) \quad \forall i \in E \\
\operatorname{telTM}_{i}={\text { daml m} 3 k l e l T t_{i}}_{i} \quad \forall i \in E \\
t e D_{i}=e l D_{i} t l D \quad \forall i \in E \\
t e S_{i}=e l S_{i} t l S \quad \forall i \in E
\end{gathered}
$$

Where:

Parameters: elEx $_{i}\left(\mathrm{~kg} / \mathrm{m}^{3}\right)$ is the emission of atmospheric pollutant $i \in E$ per $\mathrm{m}^{3}$ of ballast extracted from the quarry; $\operatorname{elTp}_{i}\left(\mathrm{~kg} / \mathrm{m}^{3}\right)$ is the emission of atmospheric pollutant $i \in E$ per $\mathrm{m}^{3}$ of ballast transported from extraction to quarry processing; $e l B e_{i}\left(\mathrm{~kg} / \mathrm{m}^{3}\right)$ is atmospheric pollutant emission $i \in E$ per $\mathrm{m}^{3}$ of ballast processed in the quarry; elTf $f_{i}\left(\mathrm{~kg} /\left(\mathrm{m}^{3} . \mathrm{km}\right)\right)$ is the emission of atmospheric pollutant $i \in E$ per $\mathrm{m}^{3}$ of transported ballast, per one kilometer, from the quarry to the railway storage site; $m 3 \mathrm{kl}\left(\mathrm{m}^{3}\right)$ is the volume of ballast used in one kilometer of track; dpal $(\mathrm{km})$ is the distance from the quarry to the railway storage site; $e l T t_{i}\left(\mathrm{~kg} /\left(\mathrm{m}^{3} . \mathrm{km}\right)\right)$ is the emission of atmospheric pollutant $i \in E$ per $\mathrm{m}^{3}$ of transported ballast, per kilometer, from the railway storage site to the railway maintenance location; $\operatorname{daml}(\mathrm{km})$ is the distance from the railway storage site to the track maintenance location; $e l D_{i}(\mathrm{~kg} / \mathrm{h})$ is the emission of atmospheric pollutant $i \in E$ per work hour of ballast unloading; $t l D(\mathrm{~h})$ is the time to do the unloading service in one kilometer of track; $e l S_{i}(\mathrm{~kg} / \mathrm{h})$ is the atmospheric pollutant emission $i \in E$ per work hour of ballast tamping; $t l S$ (h) is the time to execute the tamping service in one kilometer of track; Variables: $\operatorname{telLK}(\mathrm{kg})$ is the total emission of atmospheric pollutant $i \in E$ in the production and delivery of the ballast to be used in one kilometer of track at the maintenance location; telTM $(\mathrm{kg})$ is the total atmospheric pollutant emission $i \in E$ in ballast transportation from the storage site to the track maintenance location; $t e S_{i}$ $(\mathrm{kg})$ is the total atmospheric pollutant emission $i \in E$ in the service of tamping one kilometer of track; $t e D_{i}(\mathrm{~kg})$ is the total atmospheric pollutant emission $i \in E$ in the service of removal of the ballast in one kilometer of track.

Equations 5-8 are used to calculate the emissions of sleeper for one kilometer of track.

$$
\begin{aligned}
& t e D K_{i}=n d k d\left(e d P a_{i}+e d T p_{i} d s f d+e d D f_{i}+d f p d e d T f_{i}\right) \quad \forall i \in E \\
& \operatorname{tedTM}_{i}=\operatorname{damd} n d k d \text { edTt } t_{i} \quad \forall i \in E \\
& t e R D_{i}=t d R e d R_{i} \quad \forall i \in E \\
& t e I D_{i}=t d I \text { edI } I_{i} \quad \forall i \in E
\end{aligned}
$$


Where:

Parameters: $e d P a_{i}(\mathrm{~kg} / \mathrm{un})$ is the emission of atmospheric pollutant $i \in E$ in the metallurgic process of steel profile production for one unit of sleeper; $e d T p_{i}(\mathrm{~kg} /(\mathrm{km} . \mathrm{un}))$ is the emission of atmospheric pollutant $i \in E$ per unit of transported sleeper, per kilometer, from the metallurgic to the sleeper factory; $d s f d(\mathrm{Km})$ is the distance from the metallurgic to the sleeper factory; $e d D f_{i}(\mathrm{~kg} / \mathrm{un})$ is the emission of atmospheric pollutant $i \in E$ per unit of produced sleeper; $e d T f_{i}(\mathrm{~kg} /(\mathrm{km} . \mathrm{un}))$ is the emission of atmospheric pollutant $i \in E$ per unit of sleeper transported, per kilometer, from the sleeper factory to the railway storage site, per kilometer; $n d k d$ (Un) is the number of sleepers used in one kilometer of track (rate of sleep placement); $d f p d(\mathrm{~km})$ is the distance from the sleeper factory to the railway storage site; $\operatorname{dam} d(\mathrm{~km})$ is the distance from the railway storage site to the railway sleeper maintenance location; $e d T t_{i}(\mathrm{~kg} /(\mathrm{km} . \mathrm{un}))$ is the emission of atmospheric pollutant $i \in E$ per unit of transported sleeper, per kilometer, from the railway storage site to the maintenance location; $e d R_{i}(\mathrm{~kg} / \mathrm{h})$ is the emission of atmospheric pollutant $i \in E$ per work hour of sleeper removal service; $t d R(\mathrm{~h})$ is the time to execute the sleeper removal service in one kilometer of track; $e d I_{i}(\mathrm{~kg} / \mathrm{h})$ is the emission of atmospheric pollutant $i \in E$ per work hour of sleeper placement; $t d I(\mathrm{~h})$ is the time to do the service of sleeper placement in one kilometer of track; Variables: $t e D K_{i}(\mathrm{~kg})$ is the total emission of atmospheric pollutant $i \in E$ in the production and transport of the sleepers to be used in one kilometer of track at the maintenance location; tedTM $M_{i}(\mathrm{~kg})$ is the total emission of atmospheric pollutant $i \in E$ in the transportation of the sleepers to the railway storage site to the railway maintenance location; $t e R D_{i}(\mathrm{~kg})$ is the total emission of the atmospheric pollutant $i \in E$ in the service of sleeper removal in one kilometer of track; $t e I D_{i}(\mathrm{~kg})$ is the total emission of the atmospheric pollutant $i \in E$ in the service of sleeper placement in one kilometer of track.

Equations 9-12 are used to calculate the emissions of rail for one kilometer of track.

$$
\begin{aligned}
& \text { teTK }_{i}=n k t\left(e d P t_{i}+d s a t e d T t a_{i}\right) \quad \forall i \in E
\end{aligned}
$$

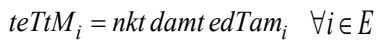

$$
\begin{aligned}
& t e R T_{i}=t t R e t R_{i} \quad \forall i \in E \\
& \text { teIT }_{i}=\text { ttI }_{\text {etI }} \quad \forall i \in E
\end{aligned}
$$

Where:

Parameters: $e^{2 P t_{i}}(\mathrm{~kg} / \mathrm{km})$ is the emission of the atmospheric pollutant $i \in E$ in the metallurgic process of production of one kilometer of rail; edTta $(\mathrm{kg} /(\mathrm{km} . \mathrm{km}))$ is the emission of the atmospheric pollutant $i \in E$ per kilometer of rail, transported by one kilometer, from the metallurgic to the railway storage site; $d s a t(\mathrm{~km})$ is the distance between the metallurgic factory and the railway storage site; $n k t(\mathrm{~km})$ is the total rail amount presented in one kilometer of track, equal to two kilometers; damt $(\mathrm{km})$ is the total distance from the railway storage site to the railway maintenance location; $\operatorname{edTam}_{i}(\mathrm{~kg} /(\mathrm{km} . \mathrm{km}))$ is the emission of the atmospheric pollutant $i \in E$ per kilometer of rail, transported by one kilometer, from the railway storage site to the track maintenance location; $e t R_{i}(\mathrm{~kg} / \mathrm{h})$ is the emission of the atmospheric pollutant $i \in E$ per work hour of the rail removal service; $t t R(\mathrm{~h})$ is the time to do the rail removal service in one kilometer of track; etI $_{i}(\mathrm{~kg} / \mathrm{h})$ is the emission of the atmospheric pollutant $i \in E$ per work hour of the rail installation service; $t t I(\mathrm{~h})$ is the time to execute the rail installation service in one kilometer of track.

Variables: $t e T K_{i}(\mathrm{~kg})$ is the emission of the atmospheric pollutant $i \in E$ in the metallurgic process of rail production \left. and its transportation to the railway storage site; ${\operatorname{tet} T M_{i}}_{i} \mathrm{~kg}\right)$ is the emission of the atmospheric pollutant $i \in E$ in the transportation of the rail from the railway storage site to the track maintenance location; $t e R T_{i}(\mathrm{~kg})$ is the total emission of the atmospheric pollutant $i \in E$ in the service of rail removal in one kilometer of track; $t e I T_{i}(\mathrm{~kg})$ is the total emission of the atmospheric pollutant $i \in E$ in the service of installing a rail in one kilometer of track.

Step 4 is finished using Equation 13, which calculates the total emissions of each pollutant $\left(E t_{i}\right)$ as the sum of the total emissions for the ballast, sleeper and rail maintenance process for all four phases.

$$
E t_{i}=t e l L K_{i}+t e l T M_{i}+t e D_{i}+t e S_{i}+t e D K_{i}+t e d T M_{i}+t e T K_{i}+t e T t M_{i}+t e R D_{i}+t e I D_{i}+t e R T_{i}+t e I T_{i} \quad \forall i \in E
$$

Step 5, the last step of the method, is an analysis of the results, consisting on the critical evaluation of the atmospheric pollutant emissions. In it the analysis and interpretations must be made according to the results obtained in the calculations done in Step 4. The analyzes of the results in Step 5 will be done by the above mentioned four phases. 


\section{Case study and data obtaining}

For the evaluation of the proposed method a case study was done for the Vitória-Minas Railway (EFVM), an important Brazilian railway, under concession of the Vale S.A company.

To evaluate the impact of the distance from the railway storage site to the maintenance location, two locations of the railroad were chosen: 1) a location close to Governador Valadares (MG) train station, 321 kilometers far from the railway storage site, and 2) a location close to Costa Lacerda (MG) train station, one of the farthest stations from the railway storage site, 566 kilometers away.

The data about ballast life cycle was obtained from Brasitália mining company, which is the ballast supplier of EFVM. First sub-stage for the ballast is Extraction. The diesel used in the ballast production process is the AS500 and its emission factors were calculated using data from Caliman (2018). The consumption was obtained from Brasitália.

Data was gathered considering: On sub-stage 3.1.1 (Extraction), the type of extraction is explosive detonation, the equipment used is a hydraulic drill. It is extracted a volume per detonation equal to $23,489 \mathrm{~m}^{3}$, consuming 3,000 liters-diesel/detonation. On sub-stage 3.1.2 (Transportation from the quarry to the crusher) it is used a bulldozer and a truck. It is produced a daily volume of $4,760 \mathrm{~m}^{3} /$ day, consuming, both equipment, 330.56 liters-diesel/day. On Sub-stage 3.1.3 (crushing process) it is used a crusher, its productivity is $400 \mathrm{~m}^{3} / \mathrm{h}$, consuming 18 liters-diesel/hour. On sub-stage 3.1.4 (transportation from the quarry to the railway storage site) the vehicle used is a Bi-truck, with capacity of $15 \mathrm{~m}^{3}$ and the distance to the storage site is $8.5 \mathrm{~km}$. The emission factors of this sub-stage were gathered through the National Atmospheric Emissions Inventory from Automotive Vehicles (Ministério do Meio Ambiente, 2013).

On sub-stage 3.1.5 (transportation from the railway storage site to the railway maintenance location) it is used a train with on GE BB-40 electric diesel locomotive pulling 40 wagons, with capacity of $22 \mathrm{~m}^{3} /$ wagon, its speed is $50 \mathrm{~km} / \mathrm{h}$, consuming 280.35 liters-diesel/hour. Locomotive GE BB-40 emissions were calculated by Carvalhaes et al. (2017). On sub-stage 3.1.6 (removal of the ballast) it is used a ballast unloader machine, it operates $1 \mathrm{~km}$ of track in 4,5h, consuming 311.18 liters-diesel/hour. On sub-stage 3.1.7 it is used a tamper machine, it operates $1 \mathrm{~km}$ of track in 6 hours, consuming 330.81 liters-diesel/hour. The emissions of sub-stages 3.1.6 and 3.1.7 were considered equal to a diesel-electric GE BB-40 locomotive.

The data about the life cycle of the sleepers were obtained from the Railway Materials Factory (Hidremec), located at Cariacica (ES), which is the steel sleeper supplier of EFVM. First sub-stage about the sleeper is 3.2.1 (metallurgic processes), which represents the production of the sleeper profiles. We used the emissions calculated by the Brazilian Steel Institute (Instituto Aço Brasil, 2012). On sub-stage 3.2.2 (transportation from the metallurgic to the sleeper factory) the sleeper steel profiles are made in the Gerdau Metallurgic Company, located in Ouro Branco - MG and are transported by train, by 671 kilometers, to Hidremec, which is the sleeper factory that supplies EFVM $(d s f d=671 \mathrm{~km})$. It is used a train with one GE BB-40 electric diesel locomotive pulling 40 wagons, with capacity of 1 tons of steel profile, speed of $50 \mathrm{~km} / \mathrm{h}$, consuming 280.35 liters-diesel/hour. On substage 3.2.3 (Sleeper Production) Hidremec factory the steel.

At Hidremec factory, the steel profile folding is done to meet the geometric shapes established by the international norms, weighting about $69,0 \mathrm{~kg}$. The machinery is powered by electrical energy. The electric generation matrix in Brazil, and in Espírito Santo, is primarily hydraulic and because of it, the emissions on this sub-stage were not considered. On substage 3.2.4 (Transportation from the Sleeper factory to the railway storage site) there is no transport, because the railway storage site is located alongside Hidremec factory, and, thus, the emissions in this sub-stage were considered zero because the distance from the producer to the railway storage site is equal to zero $(d s f d=0)$.

On sub-stage 3.2.5 (transportation from the storage site to the railway maintenance location) it is used a train with one GE BB-40 electric diesel locomotive pulling 40 wagons, with capacity of 12,480 sleepers, speed of $50 \mathrm{~km} / \mathrm{h}$, consuming 280.35 liters-diesel/hour. The daml parameter represents the distance between railway storage site and the sleeper maintenance location. The parameter nkt represents the total of rail kilometers used in one kilometer of track. It was considered equal to two kilometers because there are a pair of rails in the track. The distance traveled from the rail Metallurgic to the storage site is equal to $18,216 \mathrm{~km}$, therefore $d s a t=18,216 \mathrm{~km}$.

After, stage Sleepers removal is done. According to the EFVM maintenance team, the sleeper removal process and application of new ones use an equipment which is already available in adjacent works. Thus, it was not possible to calculate the specific value of the total work hours of this equipment. Therefore, the emissions in sub-stages 3.2.6 (Removal of sleepers) and 3.2.7 (Application of new ones) were considered zero. 
About the rail life cycle data, we obtained information from Vale S.A company and EFVM maintenance team. Currently in Brazil there is no national company that supplies rails for any railway, and it wouldn't be possible to acquire information in foreign companies. The rail manufacturing process begins with sub-stage 3.3.1 (Metallurgic process). The same emission factors of the Metallurgic process of the sleeper sub-stage was used.

On sub-stage 3.3.2 (transportation between the metallurgic and the railway storage site) the rails used in the railway are imported from Japan and transported to Brazil, it is used a Panamax ship, with capacity of 1,000 rail kilometers of TR68 rail used in the EFVM. These ships use Heavy Fuel Oil (HFO) as fuel source. Pollutant emissions by kilogram of fuel consumed were calculated by Winnes \& Fridell (2009). A ship of this size consumes on average, 10.8 tons of HFO per day (International Maritime Organization, 2015). A ship takes 33 days with speed of $552 \mathrm{~km} /$ day to travel from Port of Kobe to Vitória Port, the closest one from EFVM. On this sub-stage, only the emissions from transportation by ship were considered, as they have the highest relevance.

On sub-stage 3.3.3 (transportation from the railway storage site to the track maintenance location) it is used a train with a GE BB-40 electric diesel locomotive pulling 40 wagons, with capacity of 14.7 railway kilometers, speed of $40 \mathrm{~km} / \mathrm{h}$, consuming 280.35 liters-diesel/hour. Next sub-stages, removal of the rail and installing new rail is done using an equipment that is already available in adjacent work, similar to the sleepers. The emissions in sub-stages 3.3.4 (Removal of rails) and 3.3.5 (New rail application) were considered zero.

\section{Results and analyzes}

Following the proposed method, Step 5, the last step of the method, is the analysis of the results and must be made according to the results obtained in Step 4. Therefore, the variables, which represent the selected pollutant emissions in each phase, are calculated using Equations 1-12 after obtaining and calculating the parameters explained in Section 3. Table 1 shows the emissions factors of each pollutant at each sub-stage. Table 2 shows the main parameters used to calculated the emissions.

Table 1. Emissions factors.

\begin{tabular}{|c|c|c|c|c|c|}
\hline Elements & Sub-stage & $\mathrm{CO}_{2}$ (kg/liter-diesel) & CO (kg/liter-diesel) & $\mathrm{NO}_{\mathrm{x}}(\mathrm{kg} /$ liter-diesel) & MP (kg/liter-diesel) \\
\hline \multirow{7}{*}{ Ballast } & 3.1 .1 & 0.866 & 0.003 & 0.003 & 0.0002 \\
\hline & 3.1 .2 & 0.866 & 0.003 & 0.003 & 0.0002 \\
\hline & 3.1 .3 & 0.866 & 0.003 & 0.003 & 0.0002 \\
\hline & 3.1 .4 & 0.75487 & 0.000111 & 0.001544 & 0.000014 \\
\hline & 3.1 .5 & 2.7 & 0.0045 & 0.0443 & 0.00162 \\
\hline & 3.1 .6 & 2.7 & 0.0045 & 0.0443 & 0.00162 \\
\hline & 3.1 .7 & 2.7 & 0.0045 & 0.0443 & 0.00162 \\
\hline \multirow{7}{*}{ Sleeper } & 3.2 .1 & 1.55 & 0.00 & 0.00123 & 0.016744 \\
\hline & 3.2 .2 & 2.7 & 0.0045 & 0.0443 & 0.00162 \\
\hline & 3.2 .3 & 0 & 0 & 0 & 0 \\
\hline & 3.2 .4 & 0 & 0 & 0 & 0 \\
\hline & 3.2 .5 & 2.7 & 0.0045 & 0.0443 & 0.00162 \\
\hline & 3.2 .6 & 0 & 0 & 0 & 0 \\
\hline & 3.2 .7 & 0 & 0 & 0 & 0 \\
\hline \multirow{5}{*}{ Rail } & 3.3 .1 & 1.55 & 0 & 0.00123 & 0.016744 \\
\hline & 3.3 .2 & 3.21 & 0.0016 & 0.057 & 0.0037 \\
\hline & 3.3 .3 & 2.7 & 0.0045 & 0.0443 & 0.00162 \\
\hline & 3.3.4 & 0 & 0 & 0 & 0 \\
\hline & 3.3 .5 & 0 & 0 & 0 & 0 \\
\hline
\end{tabular}

The daml parameter represents the distance between the railway storage site and the track maintenance location. EFVM uses approximately $1.6 \mathrm{~m}^{3}$ of ballast for each meter of track. Therefore, the parameter $m 3 \mathrm{kl}$, which represents the ballast volume used in one kilometer of track is equal to $1,600 \mathrm{~m}^{3}$. This parameter is used in Equation 1.

To analyze the results, as explained in Section 3, we divided our analyses in four phases: 1) Production and material delivery (goes through the extraction of the raw materials to the delivery at the railway storage site); 2) Transportation from the railway storage site to the track maintenance location; 3) removal of the ballast, sleepers and rails and 4) Installing new ballast, sleepers and rails. Phases 3 and 4 happen at the track 
Table 2. Emission of each pollutant.

\begin{tabular}{|c|c|c|c|c|c|c|}
\hline Element & Sub-stage & Parameter & $\mathrm{CO}_{2}$ & $\mathrm{CO}$ & $\mathrm{NO}_{\mathrm{x}}$ & MP \\
\hline \multirow{7}{*}{ Ballast } & 3.1 .1 & $e^{e l E x_{i}}\left(\mathrm{~kg} / \mathrm{m}^{3}\right)$ & 0.11060 & 0.00032 & 0.00039 & 0.00003 \\
\hline & 3.1 .2 & $\operatorname{elTp}_{i}\left(\mathrm{~kg} / \mathrm{m}^{3}\right)$ & 0.06014 & 0.00018 & 0.00021 & 0.00001 \\
\hline & 3.1 .3 & $e l B e_{i}\left(\mathrm{~kg} / \mathrm{m}^{3}\right)$ & 0.03897 & 0.00011 & 0.00014 & 0.00001 \\
\hline & 3.1 .4 & $\operatorname{elTf}_{i}\left(\mathrm{~kg} / \mathrm{m}^{3} \cdot \mathrm{km}\right)$ & 0.05032 & 0.00001 & 0.00010 & 0.000001 \\
\hline & 3.1 .5 & $e l T t_{i}\left(\mathrm{~kg} / \mathrm{m}^{3} \cdot \mathrm{km}\right)$ & 0.01720 & 0.00003 & 0.00028 & 0.00001 \\
\hline & 3.1 .6 & $e l D_{i}(\mathrm{~kg} / \mathrm{h})$ & 840.186 & 1.40031 & 13.78527 & 0.50411 \\
\hline & 3.1 .7 & $e l S_{i}(\mathrm{~kg} / \mathrm{h})$ & 893.187 & 1.48864 & 14.65488 & 0.535912 \\
\hline \multirow{7}{*}{ Sleeper } & 3.2 .1 & $e d P a_{i}$ (kg/un) & 106.95 & 0.00 & 0.085 & 1.155 \\
\hline & 3.2 .2 & $e d T p_{i}$ (kg/un.km) & 0.00105 & 0.000002 & 0.000017 & 0.0000006 \\
\hline & 3.2 .3 & $e d D f_{i}$ (kg/un) & 0 & 0 & 0 & 0 \\
\hline & 3.2 .4 & $e d T f_{i} \mathrm{~kg} /(\mathrm{km} . \mathrm{un})$ & 0 & 0 & 0 & 0 \\
\hline & 3.2 .5 & $e d T t_{i}$ (kg/un.km) & 0.001213 & 0.000002 & 0.00002 & 0.0000007 \\
\hline & 3.2 .6 & $e d R_{i}(\mathrm{~kg} / \mathrm{h})$ & 0 & 0 & 0 & 0 \\
\hline & 3.2 .7 & $e d I_{i}(\mathrm{~kg} / \mathrm{h})$ & 0 & 0 & 0 & 0 \\
\hline \multirow{5}{*}{ Rail } & 3.3.1 & $e d P t_{i}(\mathrm{~kg} / \mathrm{km})$ & $105,400.00$ & 0.00 & 83.64 & 1138.59 \\
\hline & 3.3.2 & $e d T t a_{i}(\mathrm{~kg} / \mathrm{km} \mathrm{km})$ & 0.06 & 0.00003 & 0.001 & 0.00007 \\
\hline & 3.3.3 & $\operatorname{edTam}_{i}(\mathrm{~kg} / \mathrm{km} \mathrm{km})$ & 1.29 & 0.00214 & 0.02 & 0.0008 \\
\hline & 3.3.4 & $e t R_{i}(\mathrm{~kg} / \mathrm{h})$ & 0 & 0 & 0 & 0 \\
\hline & 3.3.5 & $e t I_{i}(\mathrm{~kg} / \mathrm{h})$ & 0 & 0 & 0 & 0 \\
\hline
\end{tabular}

maintenance location. Last line of Table 3 were calculated using Equation 13 of the proposed method (sum of all four phases) of each atmospheric pollutant for maintenance of one kilometer of track.

Table 3 represent, respectively, ballast life cycle pollutant emissions at the track maintenance location close to Governador Valadares and Costa Lacerda train stations. For sake of simplicity, from now on, we will mention only Governador Valadares and Costa Lacerda.

Based on Table 3, it is to be noted that there was an increase of $1.90 \%$ of the total CO2 emission, 36.30\% of the total emission of CO, 18.63\% of the total emission of NOx and $0.10 \%$ of the total emission of MP, in the maintenance of the track at Costa Lacerda, when compared to the maintenance at Governador Valadares. As such, we can see the transportation by train to the track maintenance location impacts, mainly the emission of $\mathrm{CO}$ and NOx. The $\mathrm{CO} 2$ pollutant was the most emitted in the maintenance of the track, which represents about $98.8 \%$ of the total emissions for both locations.

Based upon the information from the graphs of Figure 2 and 3, respectively, Governador Valadares and Costa Lacerda, it can be seen the influence of the ballast, the sleeper and the rail in the total pollutant emissions.

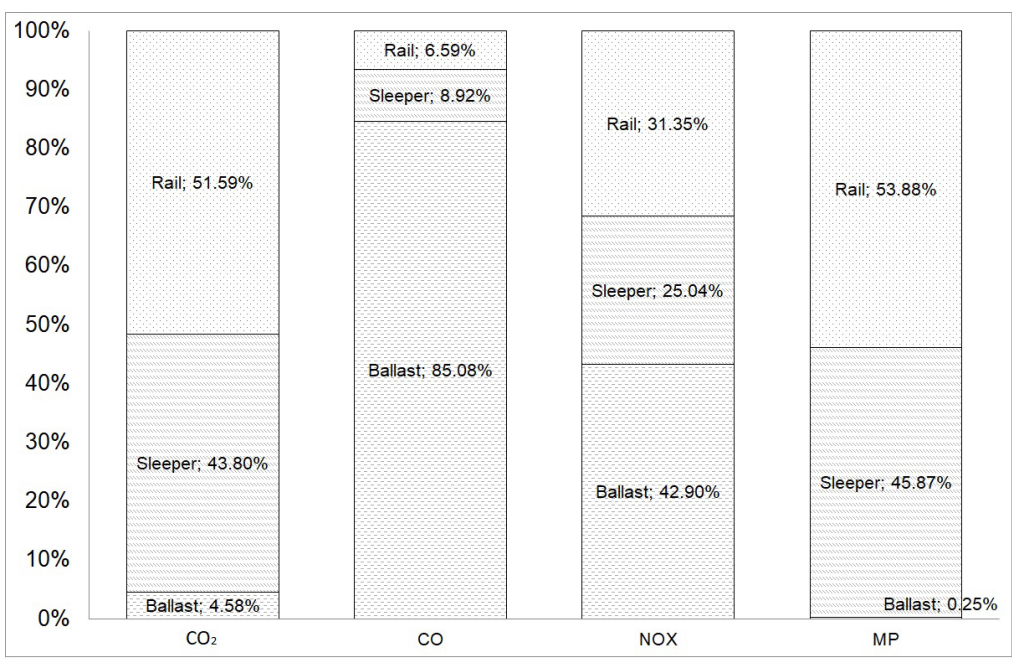

Figure 2. Emission of atmospheric pollutants at Governador Valadares of ballast, sleeper and rail during their life cycle. 
Table Emission of pollutants in Governador Valadares and Costa Lacerda.

\begin{tabular}{|c|c|c|c|c|c|c|c|c|c|c|}
\hline \multirow[t]{2}{*}{ Element } & \multirow{2}{*}{\multicolumn{2}{|c|}{ Phases }} & \multicolumn{4}{|c|}{$\begin{array}{c}\text { Emissions of pollutants - Governador } \\
\text { Valadares }(\mathrm{kg} / \mathrm{km})\end{array}$} & \multicolumn{4}{|c|}{$\begin{array}{l}\text { Emissions of pollutants - Costa Lacerda } \\
\qquad(\mathrm{kg} / \mathrm{km})\end{array}$} \\
\hline & & & $\mathrm{CO}_{2}$ & $\mathrm{CO}$ & $\mathrm{NO}_{\mathrm{x}}$ & MP & $\mathrm{CO}_{2}$ & $\mathrm{CO}$ & $\mathrm{NO}_{\mathrm{x}}$ & MP \\
\hline \multirow{6}{*}{ Ballast } & 1 & $\begin{array}{l}\text { Production and delivery of } \\
\text { materials }\left(\text { telL } K_{i}\right)\end{array}$ & $1,019.89$ & 1.11 & 2.54 & 0.09 & $1,019.89$ & 1.11 & 2.54 & 0.09 \\
\hline & 2 & $\begin{array}{l}\text { Transportation to Governador } \\
\text { Valadares }\left(\text { telTM }_{i}\right)\end{array}$ & $8,833.92$ & 15.41 & 143.81 & 5.14 & $15,576.32$ & 27.17 & 253.57 & 9.06 \\
\hline & 3 & Ballast removal $\left(t e D_{i}\right)$ & $3,780.84$ & 6.30 & 62.03 & 2.27 & $3,780.84$ & 6.30 & 62.03 & 2.27 \\
\hline & 4 & Building the ballast $\left(t e S_{i}\right)$ & $5,359.12$ & 8.93 & 87.93 & 3.22 & $5,359.12$ & 8.93 & 87.93 & 3.22 \\
\hline & Tot & & $18,993.77$ & 31.75 & 296.31 & 10.72 & $25,736.17$ & 43.51 & 406.07 & 14.64 \\
\hline & 1 & $\begin{array}{l}\text { Production and delivery of } \\
\text { materials }\left(t e D K_{i}\right)\end{array}$ & $180,859.64$ & 2.25 & 162.14 & 1940.96 & $180,859.64$ & 2.25 & 162.14 & 1940.96 \\
\hline \multirow[t]{3}{*}{ Sleeper } & 2 & $\begin{array}{l}\text { Transportation to maintenance } \\
\text { at Governador Valadares }\left(\text { ted }_{T} M_{i}\right)\end{array}$ & 654.15 & 1.08 & 10.79 & 0.38 & $1,153.42$ & 1.90 & 19.02 & 0.66 \\
\hline & 3 & Sleeper removal (teR $D_{i}$ ) & 0.00 & 0.00 & 0.00 & 0.00 & 0.00 & 0.00 & 0.00 & 0.00 \\
\hline & 4 & Installing new sleeper $\left(\right.$ teID $\left._{i}\right)$ & 0.00 & 0.00 & 0.00 & 0.00 & 0.00 & 0.00 & 0.00 & 0.00 \\
\hline \multirow{6}{*}{ Rail } & Tot & & $181,513.79$ & 3.33 & 172.93 & $1,941.34$ & $182,013.06$ & 4.15 & 181.16 & $1,941.62$ \\
\hline & 1 & $\begin{array}{l}\text { Production and delivery of } \\
\text { materials }\left(t e D K_{i}\right)\end{array}$ & $212,985.92$ & 1.09 & 203.71 & $2,279.73$ & $212,985.92$ & 1.09 & 203.71 & $2,279.73$ \\
\hline & 2 & $\begin{array}{l}\text { Transportation to maintenance } \\
\text { at Governador Valadares }\left(\text { ted } T M_{i}\right)\end{array}$ & 828.18 & 1.37 & 12.84 & 0.51 & $1,460.28$ & 2.42 & 22.64 & 0.91 \\
\hline & 3 & Rail removal $\left(t e R T_{i}\right)$ & 0.00 & 0.00 & 0.00 & 0.00 & 0.00 & 0.00 & 0.00 & 0.00 \\
\hline & & Installing new rail $\left(t e I T_{i}\right)$ & 0.00 & 0.00 & 0.00 & 0.00 & 0.00 & 0.00 & 0.00 & 0.00 \\
\hline & Tot & & $213,814.10$ & 2.46 & 216.55 & $2,280.24$ & $214,446.20$ & 3.51 & 226.35 & $2,280.64$ \\
\hline \multicolumn{3}{|l|}{$\begin{array}{l}\text { To } \\
\text { po } \\
\text { of }\end{array}$} & $414,321.66$ & 37.54 & 685.79 & $4,232.30$ & $422,195.43$ & 51.17 & 813.58 & $4,236.9$ \\
\hline
\end{tabular}

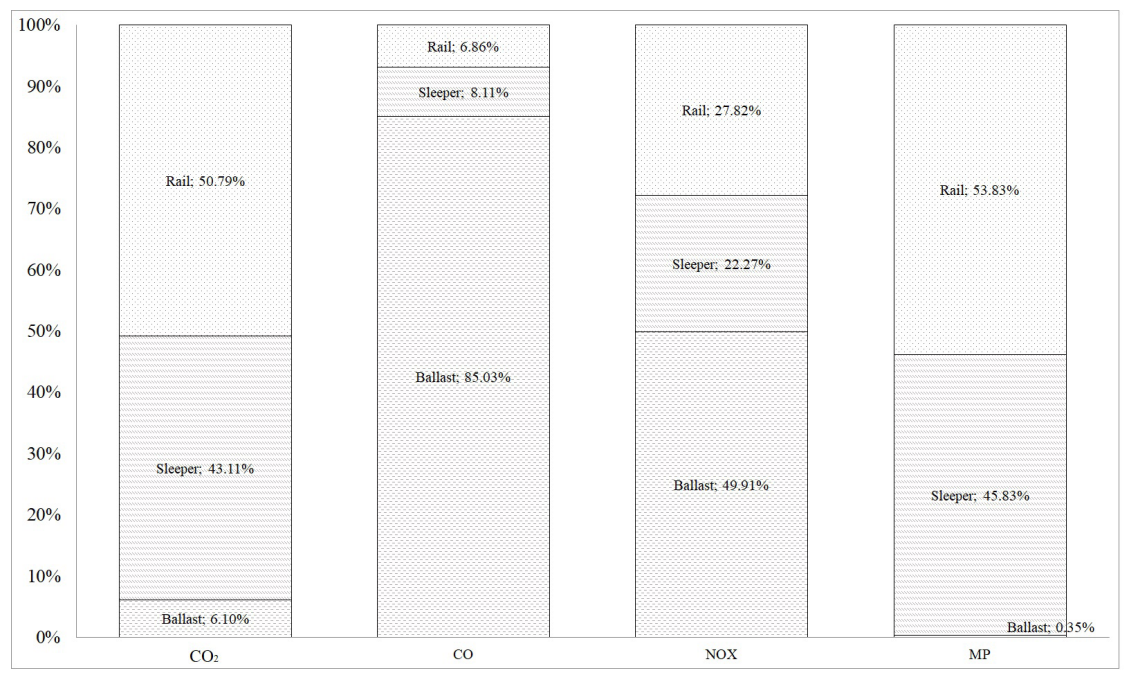

Figure 3. Emission of atmospheric pollutants at Costa Lacerda of ballast, sleeper and rail during their life cycle.

At Governador Valadares, graph of Figure 2, the $\mathrm{CO} 2$ emission is mostly significative by the rail maintenance process, which represents $51.59 \%$ of the emissions, followed by the sleeper maintenance process with $43.80 \%$ and the ballast maintenance process with $4.58 \%$. With regards to $\mathrm{CO}$, the highest emission came from the ballast maintenance process with $85.08 \%$ because in the metallurgic processes there is no CO emission, which makes the rail and sleeper maintenance process emissions lower. Regarding to NOx, the ballast maintenance process generates the highest emissions, $42.90 \%$, followed by the rail maintenance process with $31.35 \%$ and the sleeper maintenance process with 25.04\%.

About the MP, the emissions caused by the ballast maintenance process are very small; however, it is important to say that it was not considered the MP generated by the extracting process of the ballast at the quarry because 
there is no information about this emissions at Brasitália quarry. The MP values generated by the rail and the sleeper maintenance process are higher, because the metallurgic process emissions were considered.

It is noted that, with regards to sleeper and rail maintenance process the highest emissions were identified in the production and material delivery phase, which include, the metallurgic processes and transportation to the railway storage site. Our results are similar with the research done by Stripple \& Uppenberg (2010), which concluded that the highest impacts came from the acquisition of raw material and the production of the components.

But it is important to mention that we did not consider recycling the steel of the sleeper and the rail because EFVM does not have any program to do so. If EFVM decides to sell to any recycling company, it could reduce overall emissions.

Table 3 shows that for CO2, NOx and MP, the emissions caused mainly by the sleeper and the rail maintenance process, especially in the production and material delivery phase. For the ballast maintenance process, the highest emissions are caused by the transportation phase from the railway storage site to the track maintenance location. The ballast maintenance process emissions on this phase is higher than the rail and the sleeper maintenance process because, although the same locomotive is used on their transportations, the speed is different. The ballast supplier is located near the railway storage site, thus, emissions coming from the delivery phase is close to zero.

Furthermore, this result points that choosing local suppliers, closer to the railway, is an interesting strategy to reduce the emission of all pollutants. The emissions of $\mathrm{CO}$ are higher during transportation phase of the components (ballast, sleeper and rail) by train to the track maintenance location. This result shows that the choice of the railway storage site location is a main factor in the total emission of atmospheric pollutants. There, railways must analyze carefully the location of its storage site for the ballast, sleeper and rail.

The maintenance process, which includes the removal and installing the sleeper and the rail, shows values equal to zero for sleeper and rail, because the machinery used was from adjacent works. In the ballast case, the unloading and taping machines are known and it is possible to quantity the emissions.

Considering the big influence of the phase of production and material delivery, Table 4 shows, respectively, the emissions of each sub-stage composing the phase of the ballast, the sleeper and the rail, considering the track maintenance at Governador Valadares. Thus, it is possible to analyze which sub-stage is responsible for the emissions.

Table 4. Emissions of pollutants of phase Production and delivery.

\begin{tabular}{|c|c|c|c|c|c|c|}
\hline \multirow{2}{*}{ Element } & \multirow{2}{*}{\multicolumn{2}{|c|}{ Substages }} & \multicolumn{4}{|c|}{ Emissions of pollutants $(\mathrm{kg})$} \\
\hline & & & $\mathrm{CO}_{2}$ & $\mathrm{CO}$ & $\mathrm{NO}_{\mathrm{x}}$ & MP \\
\hline \multirow{6}{*}{ Ballast } & 1 & Extraction & 176.96 & 0.51 & 0.62 & 0.05 \\
\hline & 2 & Transportation from the quarry to the crusher & 96.22 & 0.29 & 0.34 & 0.02 \\
\hline & 3 & Crushing process & 62.35 & 0.176 & 0.224 & 0.02 \\
\hline & 4 & Transportation from the quarry to the railway storage site & 684.35 & 0.14 & 1.36 & 0.01 \\
\hline & Tota & & 1019.88 & 1.116 & 2.544 & 0.1 \\
\hline & 1 & Metallurgic Processes & $179,676.00$ & 0 & 142.8 & $1,940.4$ \\
\hline \multirow{3}{*}{ Sleeper } & 2 & $\begin{array}{l}\text { Transportation of steel profiles from the metallurgic to the sleeper } \\
\text { factory }\end{array}$ & $1,183.64$ & 2.25 & 19.16 & 0.68 \\
\hline & 3 & Sleeper production & 0 & 0 & 0 & 0 \\
\hline & 4 & Transportation from the sleeper factory to the railway storage site & 0 & 0 & 0 & 0 \\
\hline \multirow{3}{*}{ Rail } & Tot: & & $180,859.64$ & 2.25 & 161.96 & $1,941.08$ \\
\hline & 1 & Metallurgic processes & $210,800.00$ & 0 & 167.28 & $2,277.18$ \\
\hline & 2 & Transportation from the metallurgic to the rail storage site & $2,185.92$ & 1.09 & 36.43 & 2.55 \\
\hline \multicolumn{3}{|c|}{ Total } & $212,985.92$ & 1.09 & 203.71 & $2,279.73$ \\
\hline \multicolumn{3}{|c|}{$\begin{array}{l}\text { Total emission (ballast, sleeper and rail) of phase Production and delivery of one } \\
\text { kilometer of track. }\end{array}$} & $394,865.44$ & 4.456 & 368.214 & $4,220.91$ \\
\hline
\end{tabular}

In Phase 1 (production and delivery), the sleeper and the rail are highly impacted by the metallurgic process, which generates great impact on the emissions. The transportation sub-stage, made by train, in the case of the sleepers, or by ship, in the case of the rails, have significant emissions. It is noted that a significant part of the emission derived from the rail is due to its importing logistics process to Brazil.

Up to the 1980's, the rails were produced in Brazil, by the National Metallurgy Company (CSN). For comparison, using the proposed method, the emissions caused by the transportation of the rails from CSN metallurgic, located at Volta Redonda (MG), to the railway storage site were calculated. The distance considered is $640.0 \mathrm{~km}$. 
The graph of Figure 4 shows the comparison of the transport from the metallurgic to the railway storage site in both cases: 1) rails produced in Tokyo (Japan) and 2) rail produced at CSN metallurgic at Volta Redonda (RJ) (Brazil). The $\mathrm{CO}$ emissions are higher for the rail maintenance process because the maritime transport through long distances from the metallurgic (Japan) to the railway storage site, which generates high CO emissions.

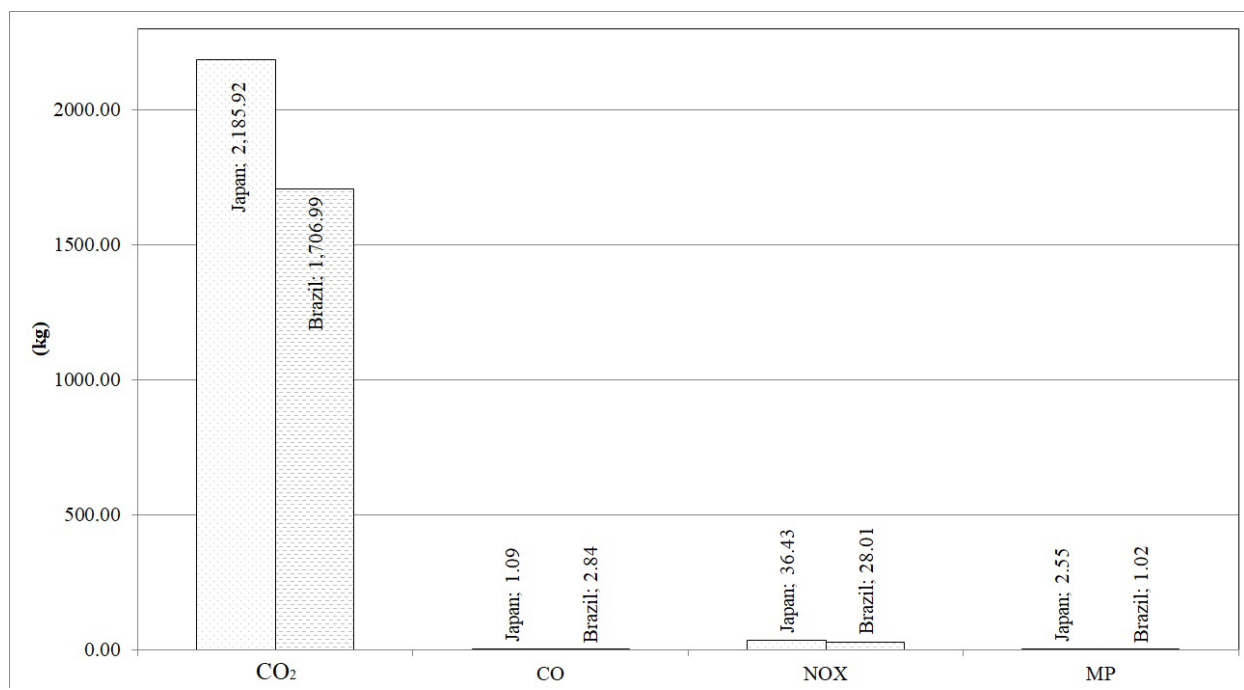

Figure 4. Emission of pollutants in the transportation from the metallurgic to the railway storage site (Japan $\times$ Brazil).

The graph in Figure 4 shows that the transportation of the rail produced in Japan has an emission of CO2 28.05\% higher than the transportation of the rail produced in Brazil, which strengthens the idea that the choice of local suppliers emits less pollutants, causing less damage to the environment. Globalization, although having several positive consequences, generates impacts to the environment due to the distance that the products have to be transported over.

Finally, it can be said that the proposed method creates a structure that is clear and complete, that can be applied by railway management of any national or international railway, of any size, that intend to develop strategies to a more sustainable rail transportation. The same can be said about government institutions, such as regulatory agencies and ministries that seek to establish laws to create limits to the rail transportation emissions.

\section{Conclusions}

The maintenance process for ballast, sleeper and rail generates atmospheric pollutant emissions. Considering this, the present paper proposes a method based on the life Cycle analysis (LCA) methodology, defined by the NBR ISO 14,040, to calculate the pollutant emissions caused by the maintenance of the ballast, sleeper and rail considering all its life cycle.

After the application of the method, it was concluded that the most emitted pollutant in the track maintenance was $\mathrm{CO}_{2}$, which represents $98.8 \%$ of the emissions, followed by MP, NOx and CO. The comparison between two maintenance locations, applying the proposed method, made clear that the transportation by train from the railway storage site to track maintenance location influences mainly the emissions of CO and NOx, presenting a raise of $36.30 \%$ and $18.63 \%$ respectively, in the maintenance at Costa Lacerda, when compared to the Governador Valadares. This demonstrates the influence of the transportation on the total emissions.

The emissions of $\mathrm{CO}$ are strongly influenced by the transportation stages up to the railway storage site, be it by train or by ship. Therefore, the choice of the location of the railway storage site is important and has a significant influence on the total emissions.

An important part of the emissions coming from the rails is due to their logistics importing process to Brazil, considering the great distance traveled by ship. For comparison, we calculated the emissions considering that Brazil could start production rail at the National Metallurgic Company (CSN), where they were produced up until the 80 's. Bringing rails from Japan, increases $\mathrm{CO}_{2}$ emission by $28.50 \%$. This strengthens the idea that reducing transportation through long distances the rails is a choice that brings less damage to the environment. 
The method showed to be successful and reached the objectives. It can be applied by railway management that intend to develop strategies that are more sustainable for the railways, as well as government institutions, such as ministries and regulatory agencies, that seek to create limits for the emissions in the rail transportation system.

As possible future work, it is suggested to extend the method for other atmospheric pollutants and to study others impact forms such as natural resources consumption and the emissions derived from discarding/ recycling the material.

\section{References}

Associação Brasileira de Normas Técnicas. (2014). Gestão ambiental - avaliação do ciclo de vida-princípio e estrutura (ABNT NBR ISO 14,040 - Versão corrigida). Rio de Janeiro: ABNT.

Associação Nacional dos Transportadores Ferroviários. (2018). Informações gerais. ANTF. Retrieved from http://www2.antf.org.br/ informacoes-gerais

Caliman, R. (2018). Proposta de um método baseado na abordagem well-to-whel para calcular e avaliar as emissões de poluentes atmosféricos e GEE durante o ciclo de vida dos combustíveis utilizados por locomotivas (Dissertação de Mestrado). Universidade Federal do Espírito Santo, Vitória.

Carvalhaes, B. B., Rosa, R. A., D’Agosto, M. A., \& Ribeiro, G. M. (2017). A method to measure the eco-efficiency of diesel locomotive. Transportation Research Part D, Transport and Environment, 51, 29-42. http://dx.doi.org/10.1016/j.trd.2016.11.031.

Instituto Aço Brasil. (2012). Relatório de sustentabilidade - 2012. IAB. Retrieved in 2019, May 02, from www.acobrasil.org.br/site2015/ downloads/relatorio_sustentabilidade_2012.pdf

International Maritime Organization. (2015). Third IMO GHG study 2014: executive summary and final report. IMO. Retrieved in 2019, May 02, from http://www.imo.org/en/OurWork/Environment/PollutionPrevention/AirPollution/Documents/Third\%20Greenhouse\%20 Gas\%20Study/GHG3\%20Executive\%20Summary\%20and\%20Report.pdf

Kiani, M., Parry, T., \& Ceney, H. (2008). Environmental life-cycle assessment of railway track beds. Proceedings of the Institution of Civil Engineers. Engineering Sustainability, 161(2), 135-142. http://dx.doi.org/10.1680/ensu.2008.161.2.135. [). Thomas Telford Ltd.]

Ministério do Meio Ambiente. (2013) Inventário nacional de emissões atmosféricas por veículos automotores rodoviários 2013: anobase 2012. MMA. Retrieved in 2019, May 02, from http://www.antt.gov.br/backend/galeria/arquivos/inventario_de_emissoes_por_ veiculos_rodoviarios_2013.pdf

Stripple, H., \& Uppenberg, S. (2010). Life cycle assessment of railways and rail transports - Application in environmental product declarations (EPDS) for the Bothnia Line. Stockholm: Swedish Environmental Research Institute.

Werner, F., \& Shragle, R. (2008). Life cycle assessment (LCA) of railway sleepers: comparison of railway sleepers made from concrete, steel, beech wood and oak wood. Bingen am Rhein: Society for Research on Wooden Railway Sleepers.

Winnes, H., \& Fridell, E. (2009). Particle emissions from ships: dependence on fuel type. Journal of the Air \& Waste Management Association, 59(12), 1391-1398. http://dx.doi.org/10.3155/1047-3289.59.12.1391. PMid:20066904. 